CIHM

Microfiche Series (Monographs)

\section{ICMH \\ Collection de microfiches (monographies)}

Canadian Institute for Historical Microreproductions / Institut canadien de microreproductions historiques
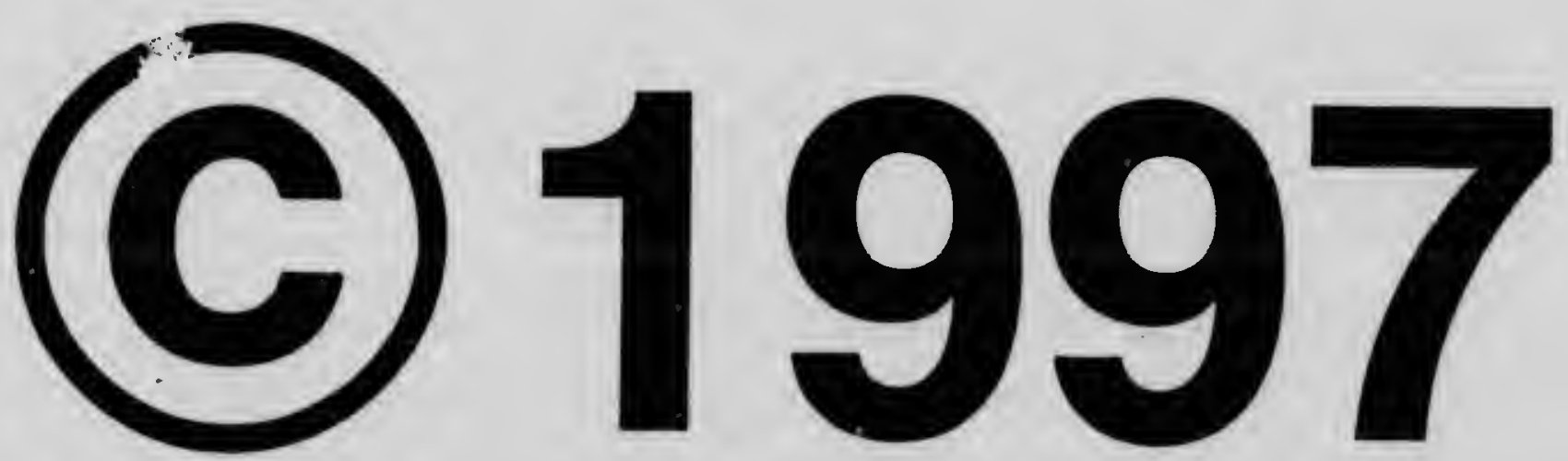


\section{Technical and Bibliographic Notes}

The Institute has attempted to obtaln the best original copy avallable for filming. Features of this copy which may be blbllographically unlque, which may alter any of the Images In the reproduction, or which may slgnificantly change the usual method of filming are checked below.

\section{Coloured covers /}

Couverture de couleur

\section{Covers damaged /}

Couverture endommagée

Covers restored and/or laminated /

Couverture restaurée et/ou pelliculée

Cover title missing / Le tltre de couverture manque

Coloured maps / Cartes géographlques en couleur

Coloured ink (i.e. other than blue or black) /

Encre de couleur (i.e. autre que bleue ou noire)

Coloured plates and/or Illustrations /

Planches et/ou illustrations en couleur

Bound with other material /

Relié avec d'autres documents

Only edition available /

Seule édition disponible

Tight binding may cause shadows or distortion along interior margin / La reliure serrée peut causer de l'ombre ou de la distorsion le long de la marge intérieure.

Blank leaves added during restorations may appear within the text. Whenever possible, these have been omitted from filming / II se peut que certaines pages blanches ajoutées lors d'une restauration apparaissent dans le texte, mais, lorsque cela était possible, ces pages n'ont pas été filmées.

Additional comments /

Commentaires supplémentaires:
L'Instltut a microfilmé le mellieur exemplaire qu'll lul a été posslble de se procurer. Les détalls de cet exemplalre qul sont peut-etre uniques du point de vue blbllographlque, qul peuvent modifler une Image reprodulte, ou qul peuvent exiger une modification dans la methode normale de filmage sont Indiqués cl-dessous.

\section{Coloured pages / Pages de couleur}

\section{Pages damaged / Pages endommagées}

Pages restored and/or laminated /

Pages restaurées et/ou pelliculées

Pages discoloured, stalned or foxed /

Pages décolorées, tachetées ou plquées

Pages detached / Pages détachées

\section{Showthrough / Transparence}

Quallty of print varies /

Qualité inégale de l'impression

Includes supplementary material /

Comprend du matóriel supplémentaire

Pages wholly or partially obscured by errata slips, tissues, etc., have been refilmed to ensure the best possible image / Les pages totalement ou partiellement obscurcies par un feuillet d'errata, une pelure, etc., ont été filmées à nouveau de façon à obtenir la meilleure image possible.

Opposing pages with varying colouration or discolourations are filmed twice to ensure the best possible image / Les pages s'opposant ayant des coloratlons variables ou des décolorations sont filmées deux fois afin d'obtenir la meilleure image possible.

Thls hom le filmed at the reduction ratio checked bolow I

Ce document eat nimb au bux to riduction Indique ch-dessous.

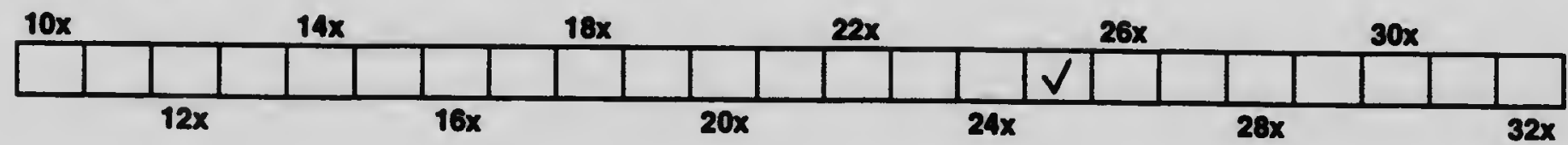


The copy fllmed here hes been reproduced thanks to the generoslty of:

\section{Lbrory \\ Agriculture Cenada}

The Images appearing here are the best quallty posslble $c$ usldering the condltion ond leglbillty of the original copy and In keoplng with the fllming contract specifleotlons.

Originel coples In printed peper covers are fllmed beglnning with the front cover and ending on the last page with e printed or lllustrated Impresslon, or the beck cover when approprlate. All other orlginal coples are fllmed beglnning on the flrst page with a printed or Illustrated Impres. slon, and ending on the last page with o printed or Illustrater Impresslon.

The last recurded frame on each mleroflehe shall contaln the symbol $\rightarrow$ Imeoning "CON. TINUED"), of the symbol $\nabla$ (meaning "END"). whlchover appllos.

Meps, plates, charts, etc., may be fllmod at difforent reduction ratlos. Those too large to be entiroly Included In one exposure are fllmed beglnning In the uppor loft hand corner, left to right and top to bottom, as many frames as required. The following dlegrams lllustrate the mothod:
L'oxemploire fllmo fut reprodult grace a la gónóroaltó de:

\section{Bibliothique \\ Apriculture Canado}

Les Imeges suiventes ont bith reprodultes avec le plus grand soln, compte tonu de la condltion et do la nottot's de l'exemplalre filmo, ot an conformits ovec les condlitons du contrat de flimage.

Les exemplaires orlglnoux dont le couverture on papler est Imprimbe sont fllmbs en commencant por lo promler plot ot on terminant solt par lo dernlare page qul comporte une emprelnte d'Impresslon ou d'illustration, solt par le second plat, selon le cas. Tous les autres exemplalres originaux sont fllmbs en commencent par la promlle pege qul comporte une emprelnte d'Impression ou d'illustration ot en torminant par le derniore page qul comporte une telle emprelnte.

Un des symboles sulvents apparaitra sur lo dernlère Image de chaque mlerofiche, selon le ces: lo symbole $\rightarrow$ slonifle "A SUIVRE". le symbolo $\nabla$ signifie "FIN".

Les cartes, planches, tableaux, otc., peuvent être fllmbs des toux de róductlon diffórents.

Lorsque le document est trop grand pour itre reprodult on un soul cllcho, II est fllimb pertlr de l'angle supórleur gauche, de gauche a drolte. ot de hout on bas, en prenant le nombre d'Images nccesselre. Les dlagremmes sulvants Illustrent la móthode.
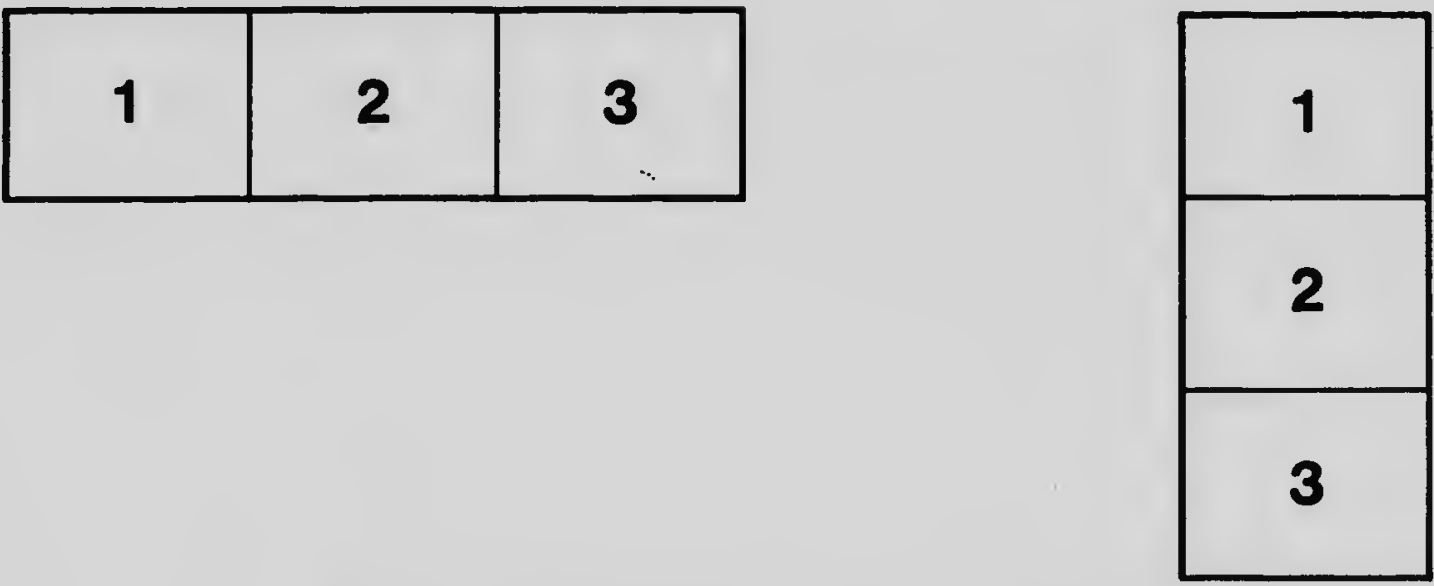

\begin{tabular}{|l|l|l|}
\hline 1 & 2 & 3 \\
\hline 4 & 5 & 6 \\
\hline
\end{tabular}




\section{MCRocoN RHOUTION TEST GHART}

(ANSI and ISO TEST CHART No. 2)
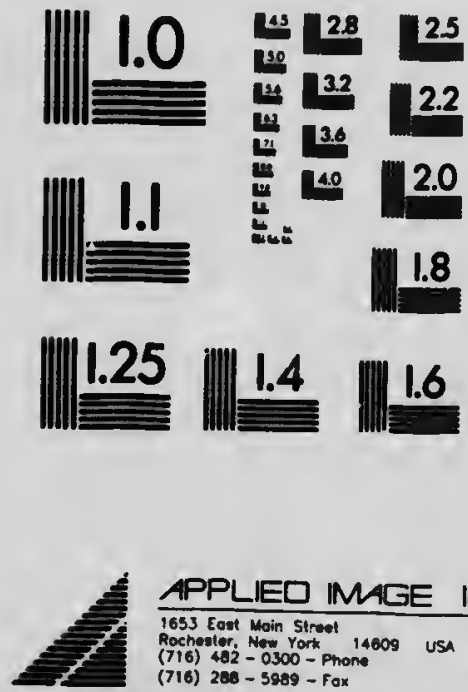

APPLIED IMAGE Inc 1653 East Wain Street Rochester. Nw York 14609 USA (716) 402 - 0300 - Phone

(716) 208 - 5989 - Fox 


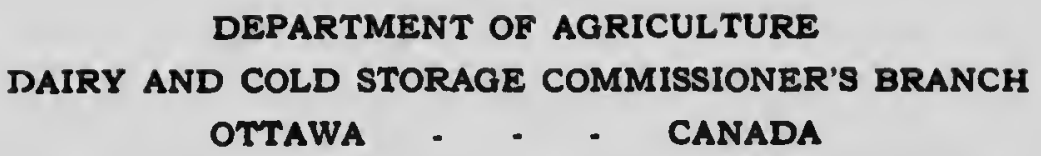

$\mathbf{*}+\cdots$

THE USE OF BRINE TANK REFRIGERATOR CARS FOR FRUIT SHIPMENT

By

EDWIN SMITH, B.S.A.

BULLETIN No. 50

DAIRY AND COLD STORAGE SERIES

Published by direction of the Hon. Martin Burrell, Minister of Agriculture, Ottawa, Ont. MARCH, 1917 


\section{LETTER OF TRANSMITTAX.}

To the Honourable the Minister of Apriculture.

sin, - I beg to submit for your approval the manuseript of $n$ report of investigations into the use of "brine ta'k" refrigerutor cars in the shipnent of fruit, which were curried out under the inmediate mupervision of the nuthor, ilr. Felwin Simith, B.S.A., formerly in charge of the Precooling and kxperimental Fruit Storage Vinrehouse at Grimshy, Ont. The rnilwny compunis's include in their equipments i number of these ears intended primarily for the earringe of ments at a low temperature. Is many of these ears loaded with ments and diriry produere ure sent into some of the fruit growing districts, it is important to kuow if they con loe used to adrnatage

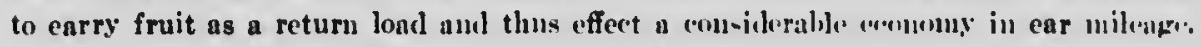

This report gives the results of trial shipments mole in British columbial and also in connection with the oppration of the Cirims ly wurchumse.

Some results already published in Bulletin So. to have been summurized and in-

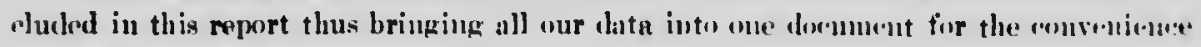
of those who may be interested in the subjeet.

I have the honour to recommend that thix report be published as Bulletin $\mathbf{X}$.. 50, Dairy and Cold Stornge Series.

I have the honour to be. sir.

Your oledient sorvant,

J. ... RI'DDICK.

Orrawd, January $30,101 \%$.

Dairy and C'sld storage Commissioner. 


\title{
THE USE OF BRINE TANK REFRIGERATOR CARS FOR FRUIT SHIPMENTS
}

\author{
BY \\ EDIVIX S.MITII, B.S.A.
}

Growers and shippers of fruits and regetables have strongly objeclid to the lirins tank refrigerator car for the shipuent of their products. Their objertions ure fubrly based upron uneatisfactory experiences and heury losses incurred owing to hiph temperatures in slipments mude with this type of refrigerator enr. The railwuys of C'anada have found this car admirnble for shipping auch jerishoble proluce as ponltry, meats and dairy products that refuire low temperatures, and, ws the shipping of fruits covers ouly a portion of the venr, and n dual purpose enr lus be'u rempired, thiy luve favored its adoption. With shippers and eonsignees ruling aguinst, mud of ton refin-iug to aceept these cars for shipment, and the railways incrensing their suplli, a problem has been presented to the l)epartment of Agrieulture which has risolvinl its(lf iuto the work of making the brine tank refrigerator cur efficient for the shipun'ut of fruits and vegetables. Since the season of 1913, when the investigntionnl wurk was slurterl, grent progress has been made toward this end, so that at the presint time musy very satisfactory shipments of tender fruits are being made in brius tunk pars, anul whippers who understand the proper methods of using them are acerpting theun for such shipinonts without c mpluint.

In using the brine tank refrigerator car for shijunents of dreswinl meats or jwultry, it. las bee'll customiry to use from 10 per cent to 20 per cent of cruslied rock salt mixed with the ire. This melts the ice rapidly, removing the hent from the interior of the car and cuusing temperatures to fall below freczing. Br the continued une of salt in re-icing, freezing temperutures are maintained in the car duriug trun-it cren in hut weather. Then fruit shipments were undertaken in these pars, the use of snlt was omitted, through the supposed danger of freezing, the ice loing put in the tnuks in block form. " ni'a" to the method of icing the bumker or bleck-ice trone of enr. Ilerein lies $t .+$. : " bas led to the unpopularity of brinc tunk ears anong fruit. shipuers.

When 2 . slowly, becac air that woula - in a separate compartment, completely slint off from the hot

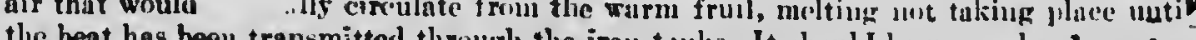
the heat has heen transmitted through the iron tauks. It shunld he more elenrly understood that ire has to welt to have its refrigeration made aruilalle for the cumliug of a refrigerutor car in just as reul a seuse as eral has to hurn to nuake its hiat avialable. The result of such methols of icing the brine touk car gnve very ligh temine ratures with a consenueut deteriorat:on nf the fruit. Thermographs placel in brine tank curs icel in this way slinw that the temperature seldom goes below $50^{\circ} \mathrm{F}$. The the rmograph record shown helow is a fair sample of such shipments. This shipment was unacle

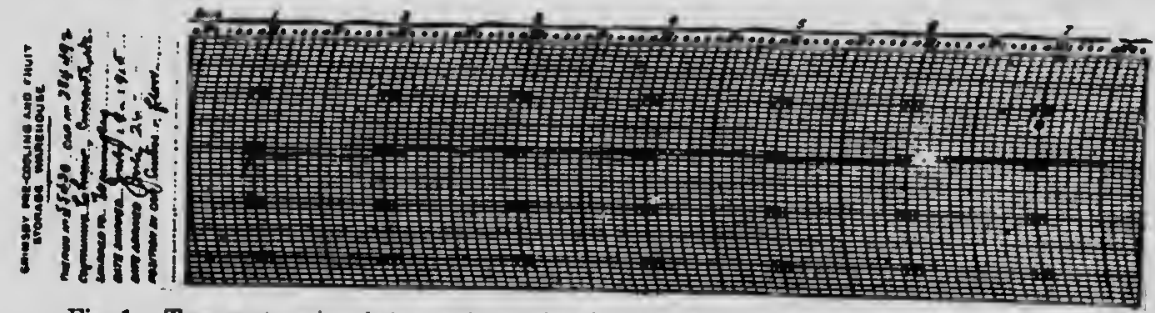

Fig. 1. Temperature in a brine tank car, in which no salt was used. Car No. 281,492 C.P. $18269-1 \frac{1}{2}$ 
Julg $18,191 \%$, with currunts, cherrien, etc., pereosled to $46^{\circ} \mathrm{F}$. before shipment and

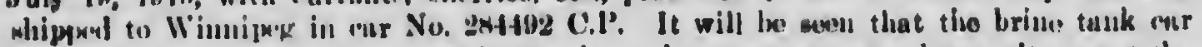
did uot furnish refrizerutim suftlent to keep the tempernture us low as it was ut the ntart, " that n purtion of the cherries showed a waste of 10 per eent upous arrival at Winuipus.

\title{
The Use of Salt and Ice for Fruit Shipments in Brine Tank Cars.
}

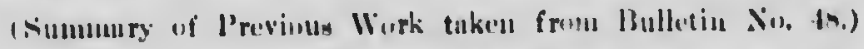

('n-operating with the Canadian l'acithe lailwuy duriup the sprink of lint, texts

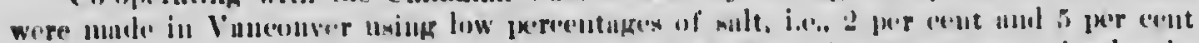

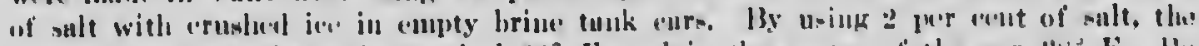

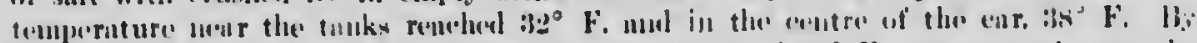

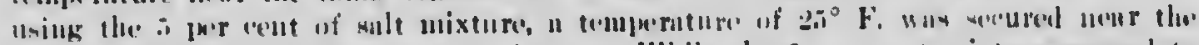

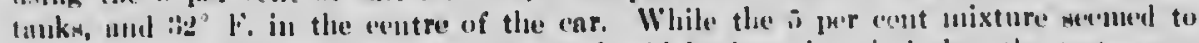
give a tomproture ton low for frut, it should be kejt in misul that the tosts were

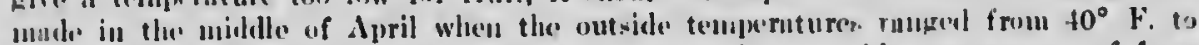

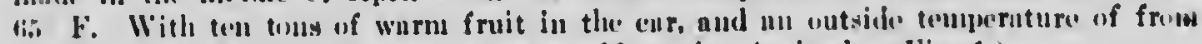
(ii) F. (1) !n $^{2}$ lo this low temperuture would not be olitnined. (Fig. 1.)

Following up this work in the sumuer of $101 \mathrm{t}$ with in shi, .nent of fruit from Sum-

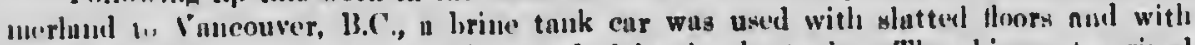
is per cent of salt incorpornted with erushed ice in the tunks. The shipment urrived in Vanconver in poul condition. The temperatures were low und there was no evidence of treceing.

\section{Demonutrations with Brine Tank Cars in 1916.}

With the co-nperation of the Canadian Pacific and the Grand Trunk Railways, arrangencuts were unde tu use brine tank refrigerators for two cars of fruit that where purchused for experimentul whipment from Grimsb; to Wimuipeg during the past s(ul:ull, in order to curry the work further, using the salt mixture with precooled fruit.

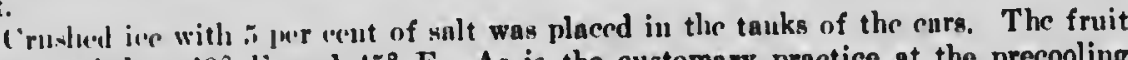
wis preneroled to $40^{\circ} \mathrm{l}$. mad $45^{\circ} \mathrm{F}$. As is the customary practice at the preconling plant with ull shipments of precooled fruita, slatted false flonrs were placed in the cars. $\Lambda$ thermusruph wus placed on the floor agninst the ice tanks to renorl the lowest temperutures luring trmusit and one was placed on top of the lond of fruit in the ('utre of the car to record the highest temperature to which the fruit would be exposed while in the e'ur. The fruit was londed and braced in the usual manner and the donrwaled with sulphite paper. On September 20, car No. 284024 C.P. (Fig. 2) was shipperl to Wiunipug, renuiring four aud one-half days to rcach its destination. On September 233. ('ar No. 340053 C.T.P. (Fig. 3) was shipped to the same point requiring approximatoly five dass to reach it: destination. Block ice without salt was used for re-icing during trausit.

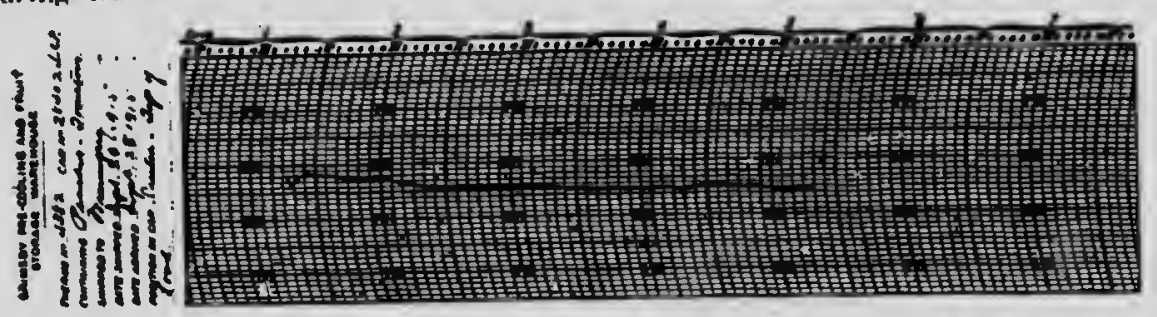

Vig. 2. Temperature record, top of load of fruit, centre of car No. C.P. 284,024. 


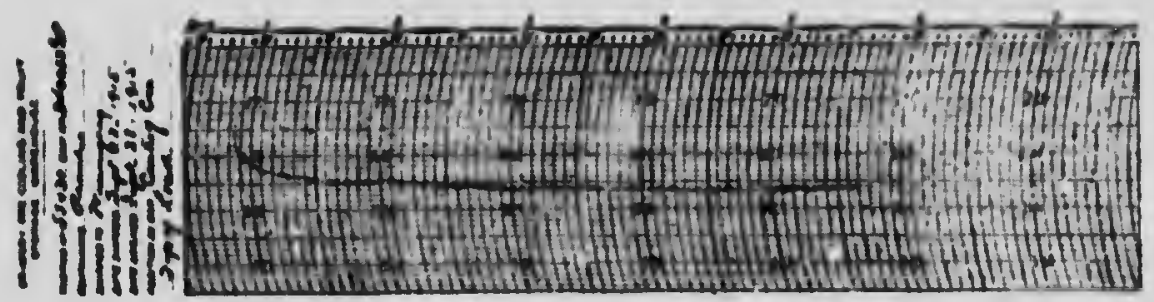

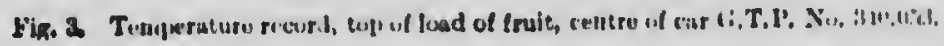

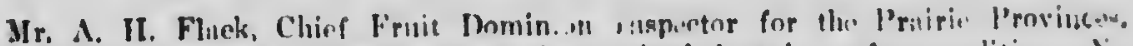

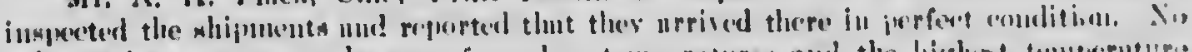

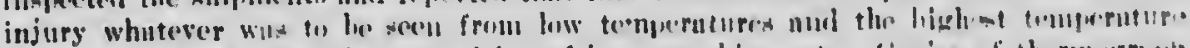

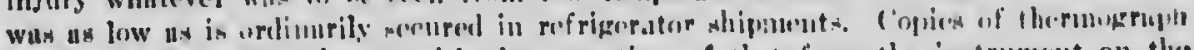

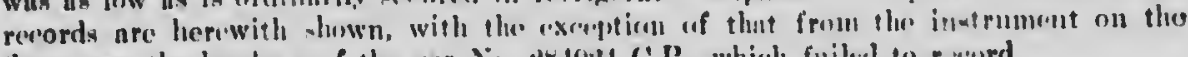

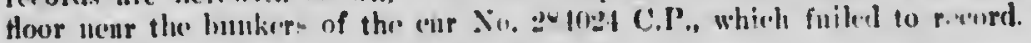

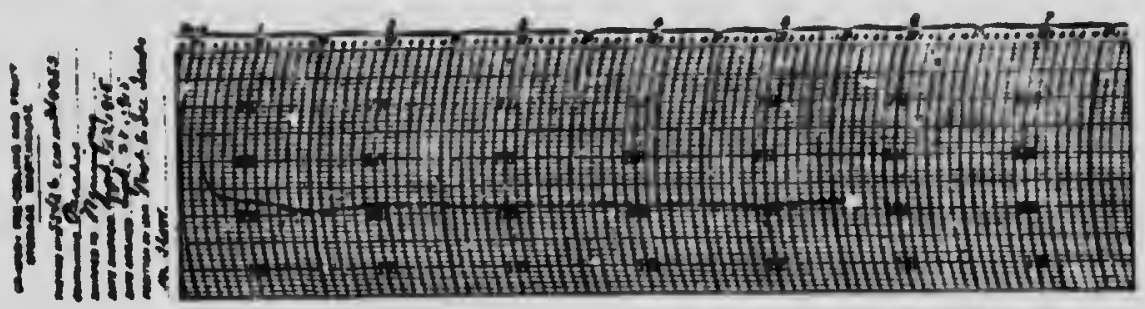

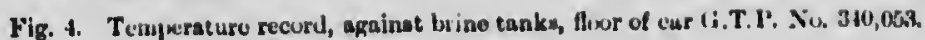

\section{Int satigations in 1916.}

During the lot senann of 1010 the inudequary of orliuurs refrigerntor ents without the use of salt was very manifest. This is well shown in thermugrnph recorl

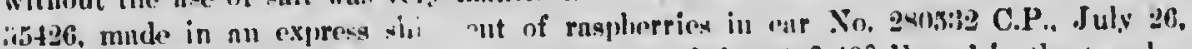

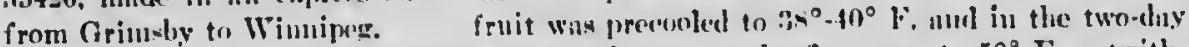
shipment, the temperature in the renter of the cur ou the flowr rose to in ${ }^{\circ} \mathrm{F}$. untwith. standing that the rar was under ine the entiro way.

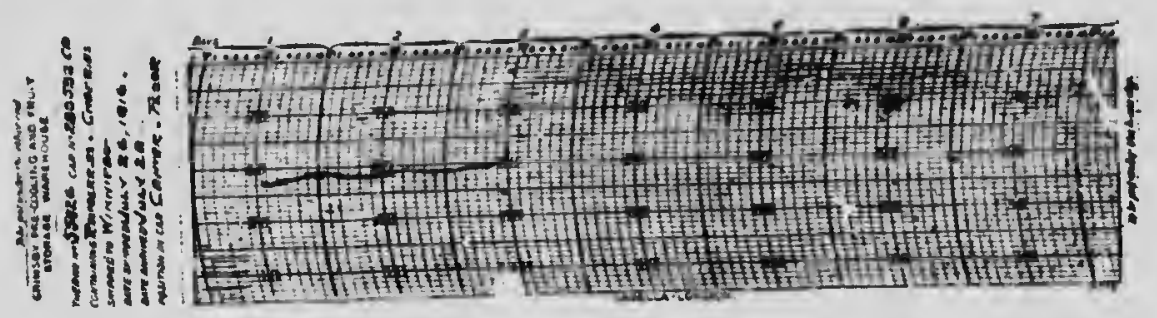

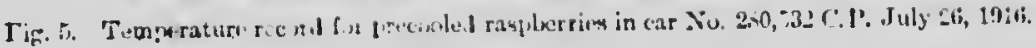

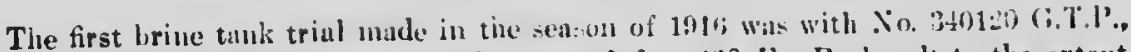
Grimsby to Winniper, with sour cherries precooled to $4: 3^{\circ} \mathrm{F}$. Roek sult to the cxtent of 400 pousus was added previous to shipment, without instructions to uso salt in 


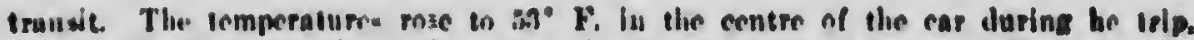

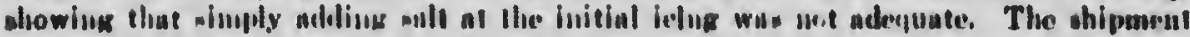
rewulted in a herovy lowo.

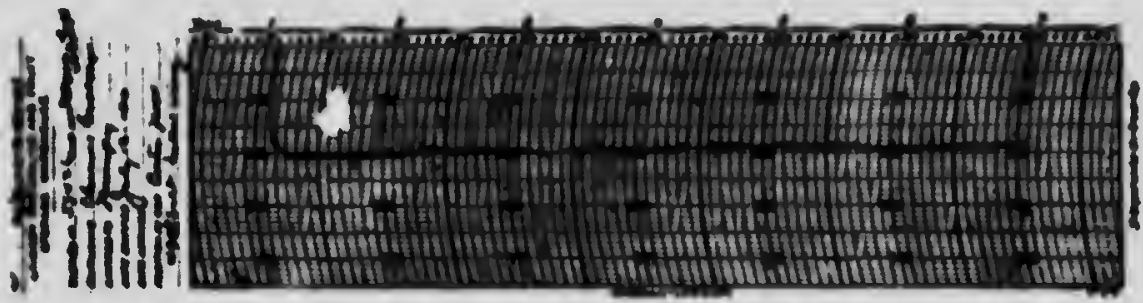

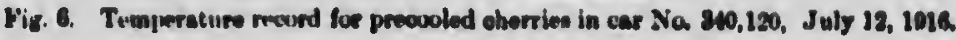

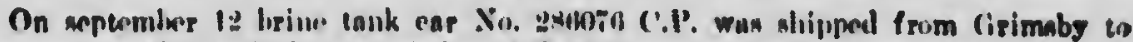
Brasudoul, coulaining fruil preesoled in $30^{\circ}$ with inwiructions to use s per eent salo

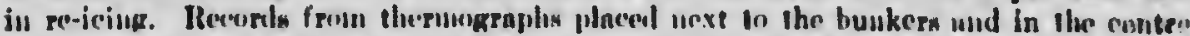
of the car whow aratifying resulis. Son injury from low temprenalure cecourred and the feui arrived in aplendid condition.

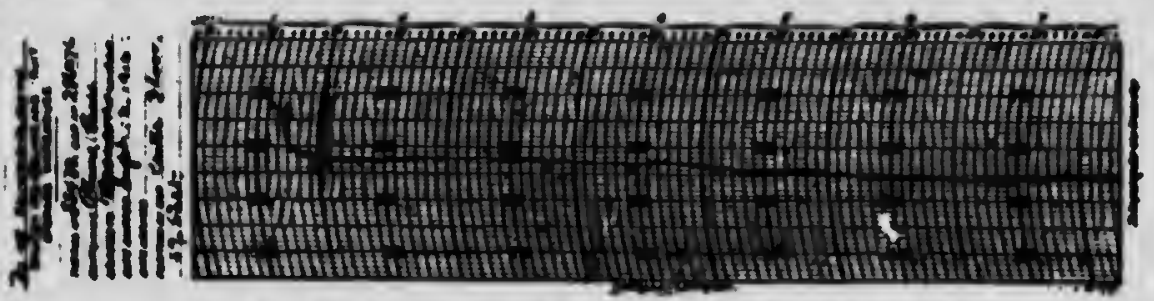

Fis. :. Brine Tunk Retrigentor Car No. 2s,0ic C.P., 8 per oent malt used in moleing. Thermegrafh reomd made on aone in oentero of car.

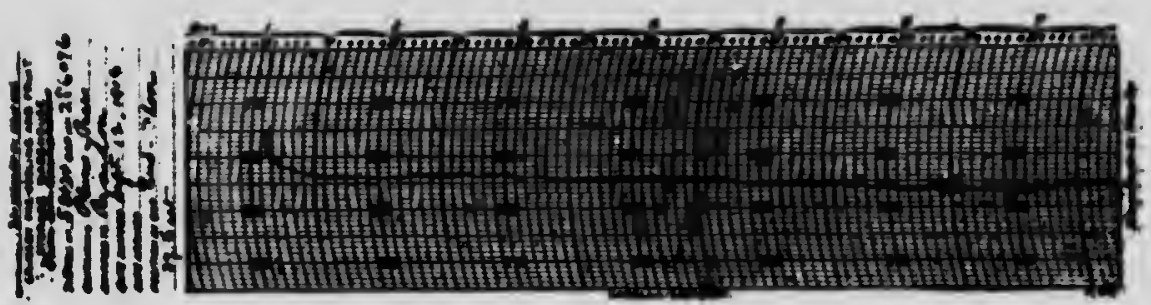

Fig. 8. Thermograph wade on Loot in ead of car Na 289,076

Similar instruetions were iseued with brine tank refrigerutor car No. 2800 t1, ahipped Septenslu.r 1is Io Deloraiue, Man. The tenuperature in the centre of the car is shown herewitl.

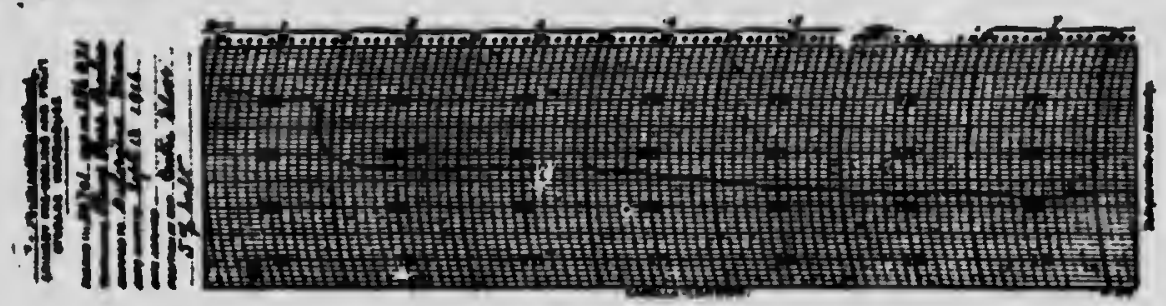

Fig. 9. Recond of Brine Tank Car No. 206,0:1 to Deloraime, Man. 


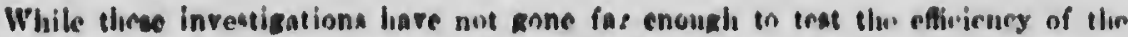

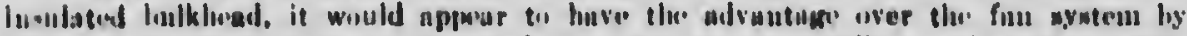

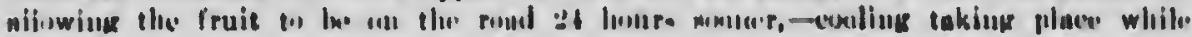
rullins.

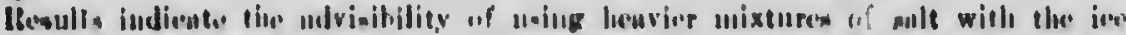

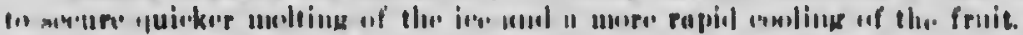

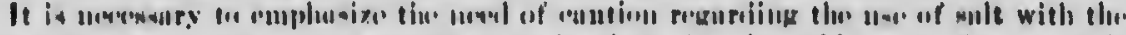

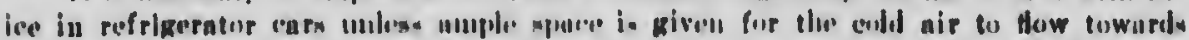

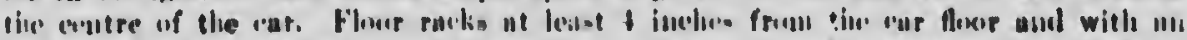

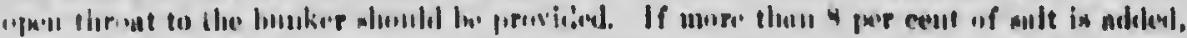

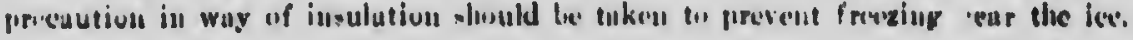

\section{Floor Racks, Fnd Bulkheads and Splash-boards.}

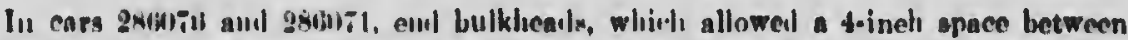

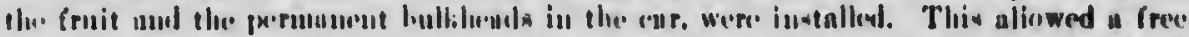

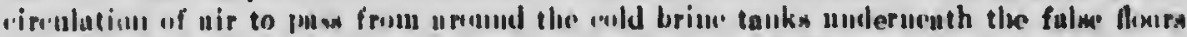

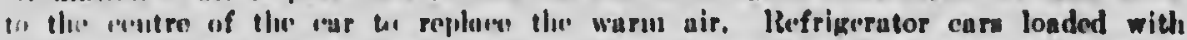

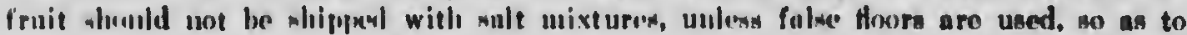

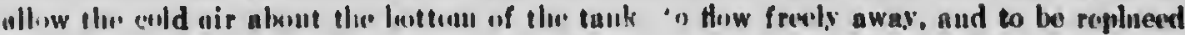

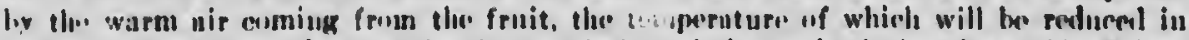
IIIII. Danker frum frowing in the proximity of the tunks is inminent if efficient P.slwi Henres are not uned.

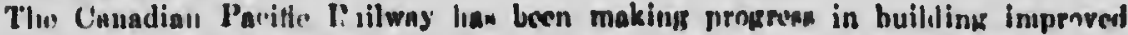
soirikerntur cars of the lorine tnuk type, the must urtable improvement being in the

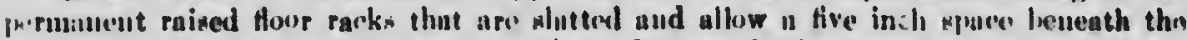
luad fer the eold air to rirrulate frum the ends towards the peutre of the car. Thewe

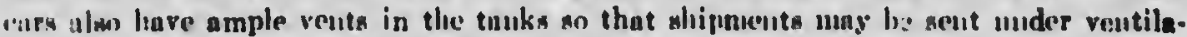

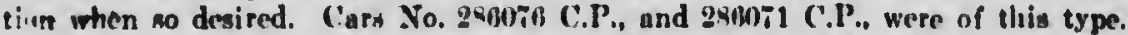

Aside from needed inuprovenent in tho iusulation aud floors of the general run

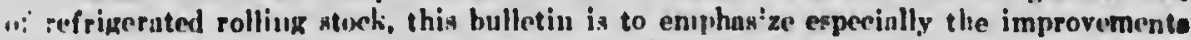
1: islid to carry the rof rigerution from the hunkers or brine tanks to the centre of thr

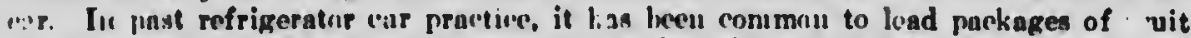
siuarely up against the lumkers and truat to the cold air reachnge the centre o i " rit thruugh insignificant erucks or apaces between tho fruit pnekuges. The $i_{1}$... ..

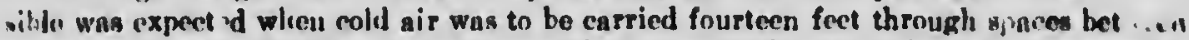
puctiagen of warm fruit and have it keep the centro of the ear cool. In surly cumes the risult has been that the fruit near tho ico eooled down, but that fariser away has

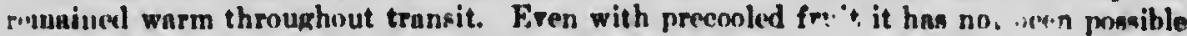
t. . induet ample refriperution to the eentre of the ear to wreseme the IPsnamimainn of lieat through the doors and insulation, so that temperti:s: actually raise whils tl: - car iq under ies.

First of all refrigerator ears are in need of an open space underneath the load ferm the ire to the eentre of the enr, and this in areomplished by havine slatter floorn lilurd permanently in the cars from four to six inches above the insulated flone of this ind. This spnce must have an open throat to a space about the ice or tho brine tanks. In most refrigerator ears at the present time (the newest types with perinaIn:ut flowr racks are also subject to this critieism), a splash-bonrd is eonstructed high rnough and near enough to the bond to shut off the free pasenge of air. In dingrnmy 1 unil 3 piges 12 and 13 is shown the result when fruit is loaded in tho par. The coll air it daninied up before it can rench tho open channel made by the flom racks. The impurtanm of this has brell throroughly demonstrated; heat must travel is conrection currents to make rapid progreas, and the benefits of foor raeks will be '? st if they are - not modered efficient at their throats. In dianram 3 on page 14 is shuwn the splash. board property located. In making shipments in car No. 286076 C.P., and 286071 
C.P., such a throat was male by ripping up a slat of the floor and installing an end lmlkhend us show' in diagram 4 on page 15. This allowed a free circuhtion of ni. nhout the whole loml nul resulted in satisfuctory temperutures.

One the ear is constructed so that refrigeration inny be conlucted to the "(utre of the corr sult nuy be upplied freely to the iee in order to relense the refrikerntion: quickly, - the colder the nir being in one part of the car, the more aletive will he the (ireulation of air to the warmer parts.

Without the use of salt witl crusled ice the brinc tnnk refrigurator car is inc!ticient und unsatisfuctory for use with frnit slipments.

The use of 5 per cent salt with crusherl ice in eonjnnetion with slatted floor rucks las improved the temumernture conditions in brine tank anrs. With these metheds a good hrine tank car has given very ronch onore satisfuctory results than n poor blockice car.

Neither freczing nor injury from low temperatures oreur with the nice of 5 per eent salt with crushed ire whon slatted llowr racks nre used. The floor rasks proverent the damming-up of the cold air ut the bawe of the tanks nud ullow it to flow frecly to the ceutre of the eir.

All obstncles blocking the opening between the tanks and the spare muderumath the floor rneks should be removed. Where aplash-boards permunently- blowk the opening end bulkheats, proviling snch an opening, should lie used.

It is neressary for slippers to closely follow the meth ls ontlined in lomling ears and to include in their iring instructions on the bill of lading "lio-ire, nsing 5 jer cent salt with erusherl ire."

It is unessary for the rnilway enmpanies to provide ieing stntions with rrushed rook salt and fncilitios for erushing the ice. It is to their interest to encouringe t tie proper londing and billing of these cars and to give them speriul uttention at all iring tations.

\section{New System of Pre-cooling.}

Thenretically it is neersesn ry to ume 2.1 tons redrigerntion to remove lecelt sufficiant to lower the tempernturo of 30,000 poumls of fruit from $80^{\circ} \mathrm{F}$. to $40^{\circ} \mathrm{F}$. In :u.tuil

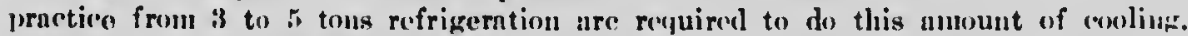
depending upon the officiency of appliention. The differenes, Inetween $2 \cdot 1$ tors: refrigerntion und the actunl amount used in practice is taken to offert lose through he"st from friotion, hent in equipment and transmission of lent througlt insulation.

The averago rofrigerator enr has kpace for 4 tons of iero. (refrigeration). In tian

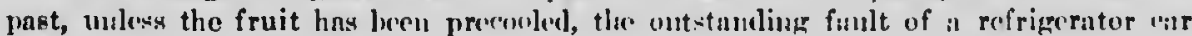

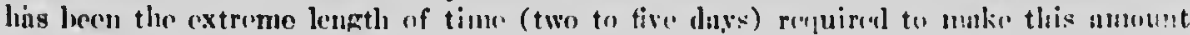

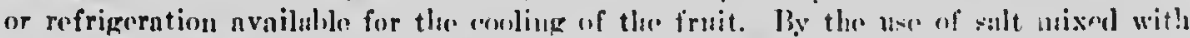

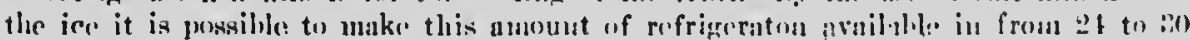
lonrs from the time the ice is pliated in the car ancl. if tho refriprerition is properly

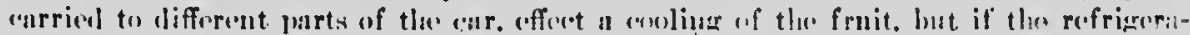

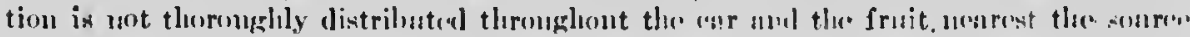

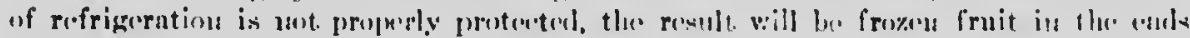
of the car with whrm fruit in the contre.

The principle of this system of precooling is to senure refrigeration in yuantitios gront enongla to cool down the lond of fruit in the g.t hours following londiag hy

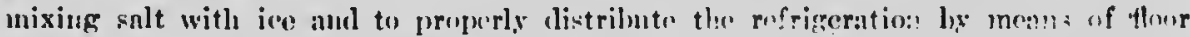
racks, cud hilk-lieads and eitlier ilestric faus or natural cirenlation through fravity. Protection from freczing by radintion of heat from the fruit nearest the bunkers $t$ (1) the melting ice may he effected hy having the end-lulkheads inallater', or by having them ennstructed so as to Ienve in air spmee between the fruit and the hunker with a

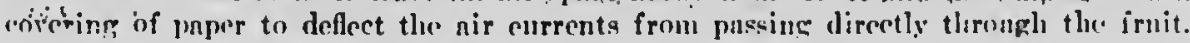

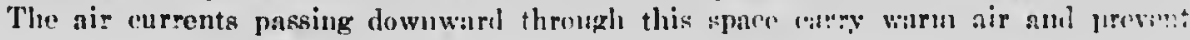


freezing. With our inrestigations thus far the end-bulkheads hare hem male with a 4-inch air space with two-ply of building puper on the side noareat :ho fruit, ovel' hupping at the sides and hottom. Tests huve been made both with using olertrie funcis to circulate the air and by using natural circulation by gravity, alluwing the cur to stand on tho track for 24 hours while eooling.

Experimentul work was sturted with this system in April of 1916, l,y fluring :แu

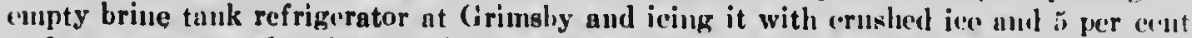
und 10 per cont salt mixture. The car wus equipued with paper-linel cul-hulkhiuls and fulse tloors four inches from the floor, so that a duct for continnous uir cinculation wus mude from the top of the bulkheads to the bottoun and centru of the "ill. 'lhis test wus mudo to determino if sufficicut air current could be establishor to myullize the temperaturo at tho ends of the enr with that at the ecut re to such a cheree as

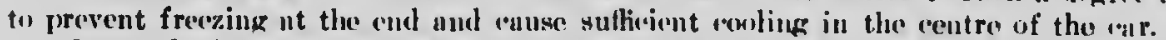

One end of tho ear was loakd with enpty puch hoxes in tho customary number. liy means of mercurinl extension thermometors and thorinographs, the teinperatures were taken at the floor near the lunkers, and at the top of the load in the contre of thic 'alr. $\Lambda$ 16-inch eloctric fall was plueed about four feet from tho ico bunker ncur thu. rouf, sending tho warm air towarls the. ice.

The test showed that with 5 per ent salt only 1 short time was repuired for the 1ti-inch fan to bring the temperature in the centre of the car to that at the base of the brino tanks. Ising 10 per eent sult the temperatures were eyualized to within une digree, the warm air in the centre of the ear displacing the eold at the hase of the tauks and distributing it about the fruit packnges. By using 10 per eent salt in ome end and an oil heater in tho eentre of the car to unhalaneo temporature roulitions

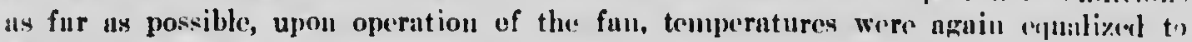
withiı one degree.

Using 10 per cent salt mixtures in both ends of the o:ar, the minimum temper:ıture was serurel in the centre of the enr while operatiug the fall. This tompruture

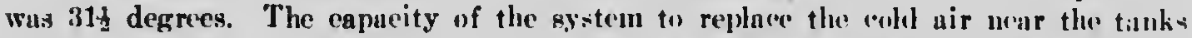
with the warm air nenr the eentre of the ear was here shown whon tomporature's at the top of the loul in tho centre were muintnined at in lower point than al the bottoun near the tanks. Without using the fan about $\tau^{\circ}$ F. difference was observed hetwoen! the temperature at the end of the enr and iu the ecutre.

These observations guve encouragenent that rosulted in muking tests in September with loaded refrigerator cars using this systen of preconlinf. 'Three cars wer" shippel from St. Catharines to Wimipeg and two rars from Ciriuslyy to Camrose. Alt?.

At hoth places cars were equipped similarly. Flowr racks were anstrueted it

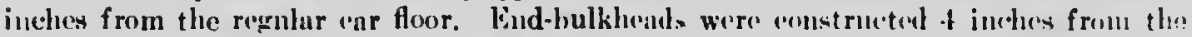

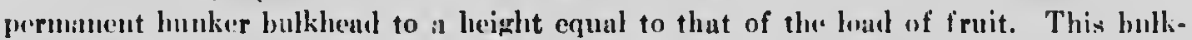
head was lined with two ply of huilding paper. The ear was londed to the rontre athel

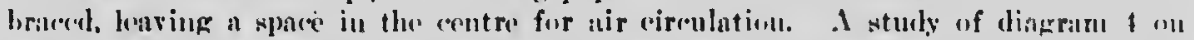

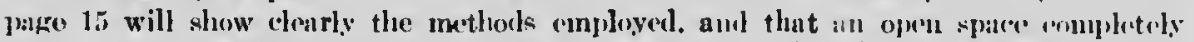
-nrrounds the loud of fruit, providing free passage-way for air circulntinu. Tho lii-

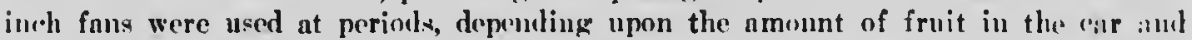
mon the amount of salt used with the ice. The cars were iced at the time of louling. the ieo: heing either broken up or crushed to secure a more satisfactory mixture nith the walt.

Ou aconut of the long period of londing renuired at St. Catharinew, hut from is

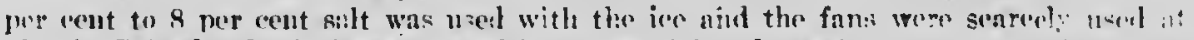
all. At Grimsby the fruit was plaeed in the ('ar, jeing done with 8 per cent salt and thi fun operated for 24 lours. The latter results were more satisfnctory as will le: whown by the thermograph records which tell the story araphicnlly.

The fruit cooled in these eare registered $04^{\circ} \mathrm{F}$. up to $70^{\circ} \mathrm{F}$. at the time of placing in the car. This tempernture is from $10^{\circ}$ to $20^{\circ}$ lower than would be the 'nwe in .July. 


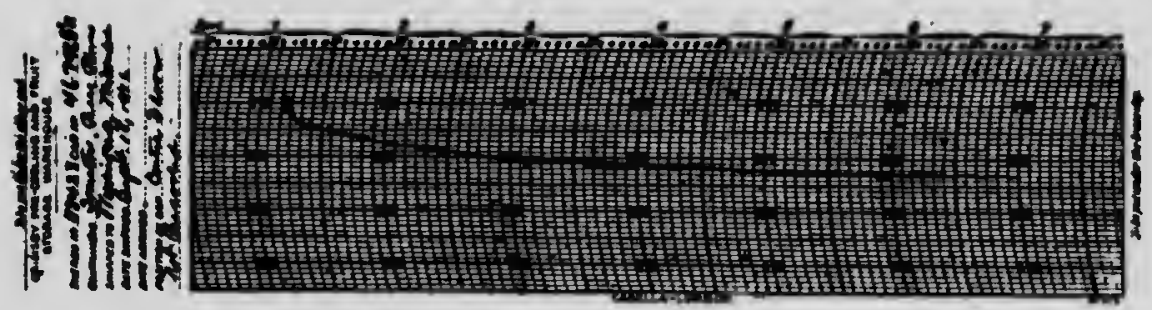

Fig. 10. Temperature recond in car No. 46796 (:.T. whippod from St. Catharines, Septernber 18, 1916, without precuoling. Teuperature taken in centre of car on the foor. Typioal of a'non. precuoled shipment.

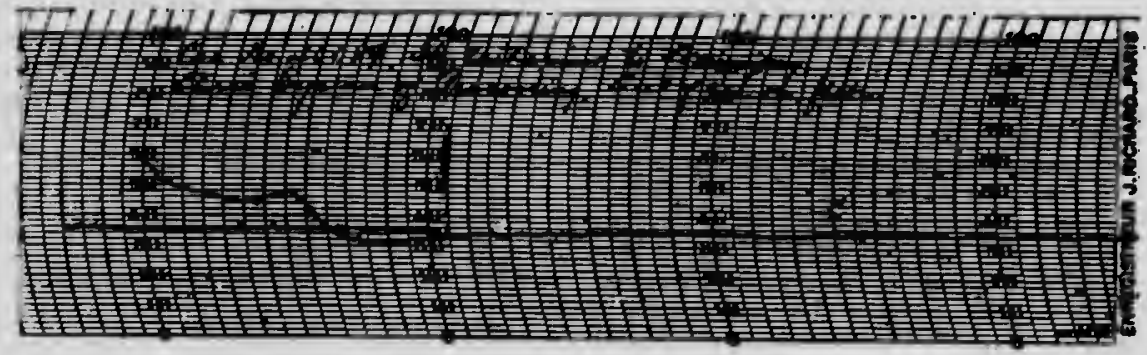

Fir. 11. Temprrature reoord in car No. 46,639 G.T. Shipped nom St. Cutharines, September 18, 1916, cur precuoling. 6 per cont walt used. No salt used in transit. Thermograph placed in a basket on the floor of tho car against the end balk-heads.

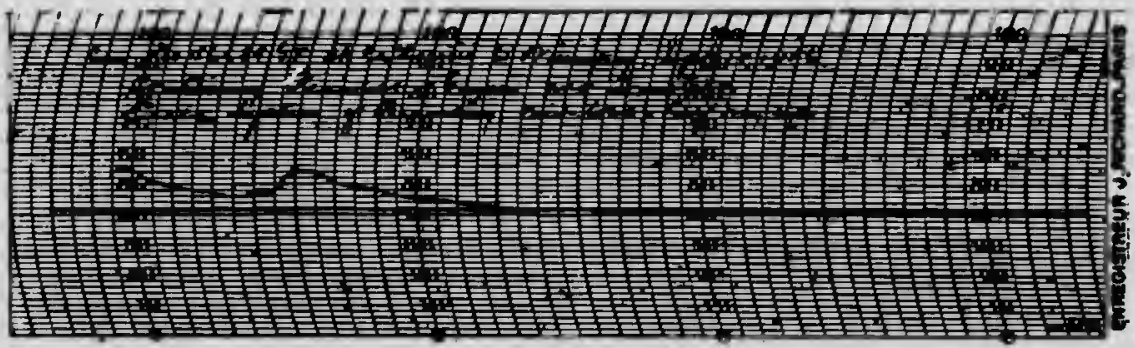

Fig. 12. Temperature recont in car No. 40,68y G. T. Thermograph placed in a basket half was butween floor and top of load; half way between ice bunker and centre of oar.

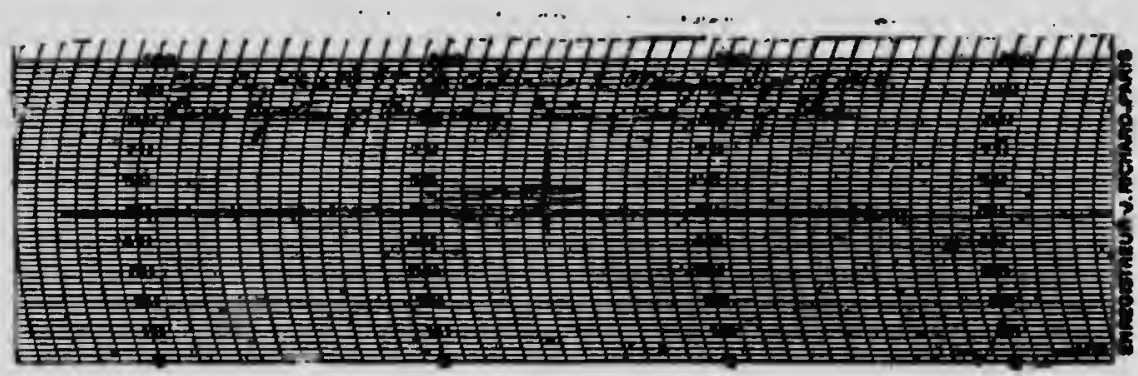

Fig. 13. Temperature record in car No. 46,689 G.T. Thermograph pleced in a basket in the top tier of the lond in the centre of the arr. 


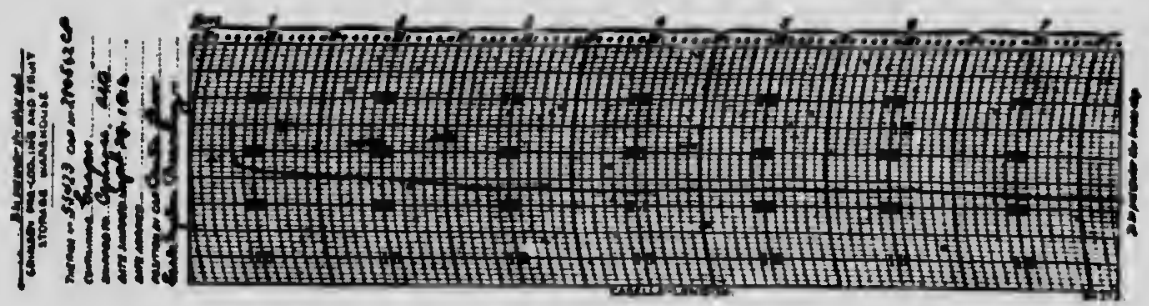

Fig. 14. Temperature reoord in car No. 280,562 C.P. Shipped from (irimaby to Canurume, $A$ lta., September 29, 1916. Car precooling. 8 per cent anlt usd. No salt in tranxit. Thi ruicgraphis liaced on the floor in crentre of the car.

Reprorts on the ears showed that they arrived at their destinntion in perfect conditiol. although this is partially due to the cool weather in September und to the kimi- of fruit shipped (peaches, tomatoes, pears and grapes.) The MoNaupht:.. Fruit Company of Winnipeg stated thut ear No. $466 \times 3$ (1.'T.. Wus the most intinfartory 'ar of fruit they had ever received from the Provinee of Ontario.

$I_{l_{i}}$ stud, ving the thermograph records, it will be sceen that car No. $280 \%$ a 2 ('.P., naidutinined an execptionally good temuperature. Shipments at this time of yenr murt with conl wenther. which has to be taken into consideration in applying the remilts to Il uly couditious.

\section{Conclusions.}

The results of the first season's tents slow that it is possible to precool fruits in cars using for refrigeration the ice in the bunkers without luss from freezing. 'The. rang" "fooling in the tests was not as great as desired, this being the result of unt using hedrs enough salt mixture.

By using an electric fan in eneh end of the ear for 24 hours previous to shipmient. the costing in the ceatre of the cur is equalized with that in the end of the cur.

It is sufe to use up to 10 per eent salt witl crushed iere, but if heavier mixtures: are fruit aud the ice or clse fans used to eireulate the air, eausing the warm air from the centrs of the ear to flow down through the end bulkhead air spaee between the fruic and the ice. 


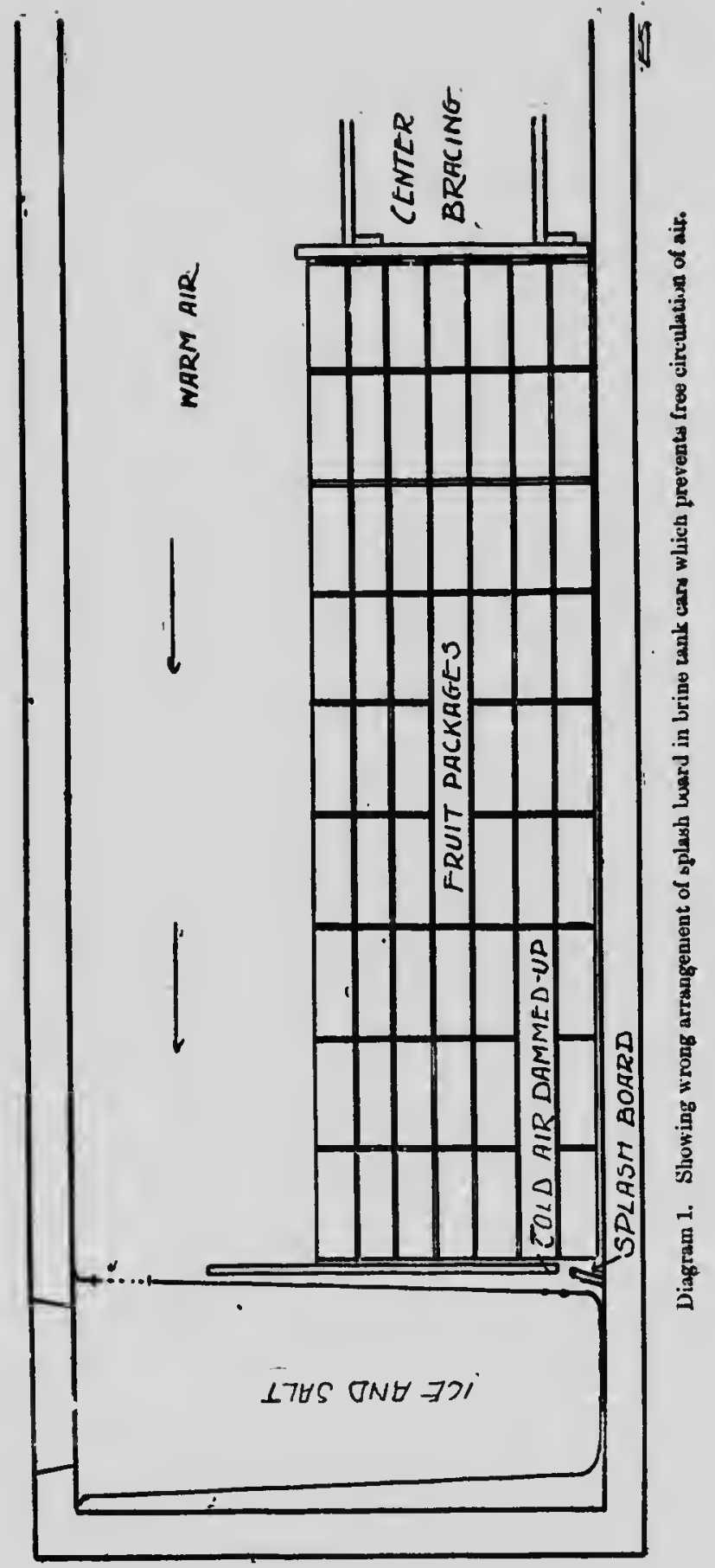




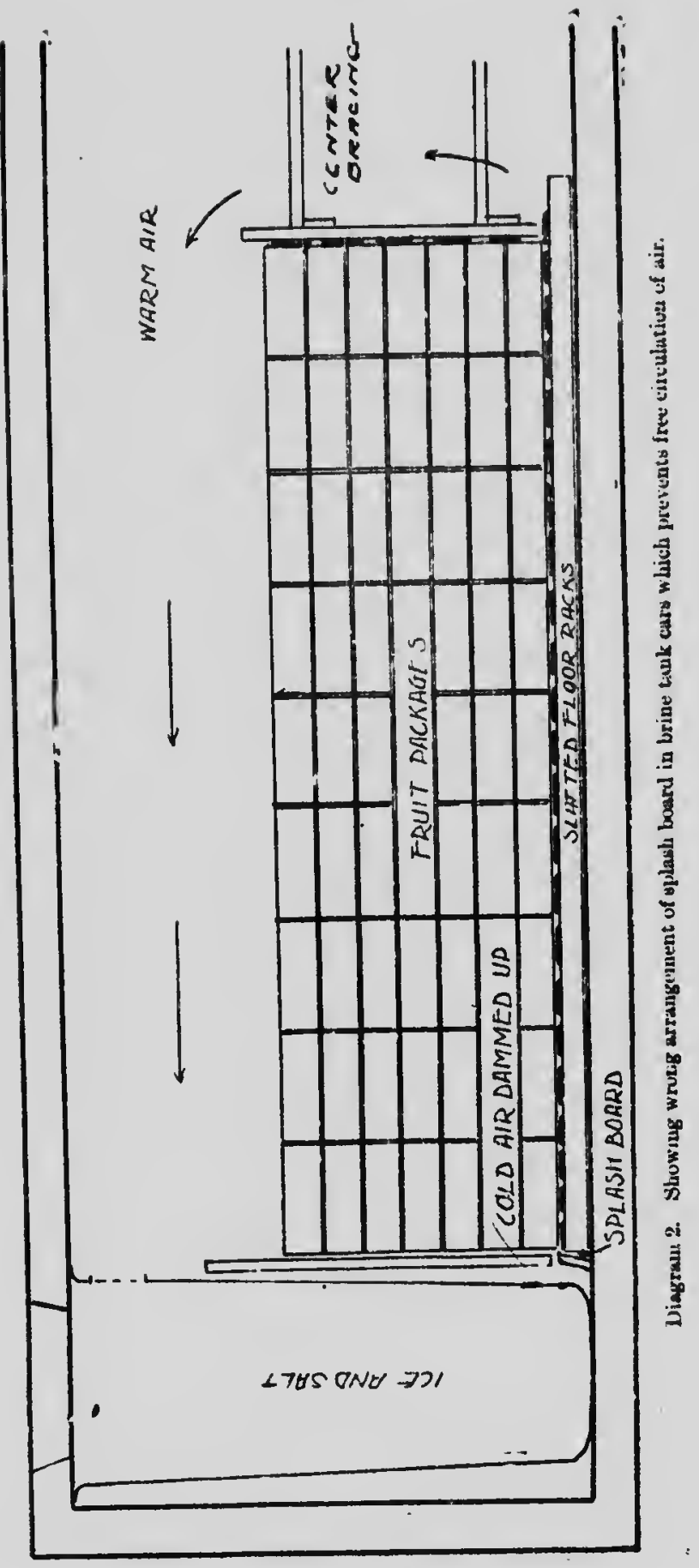




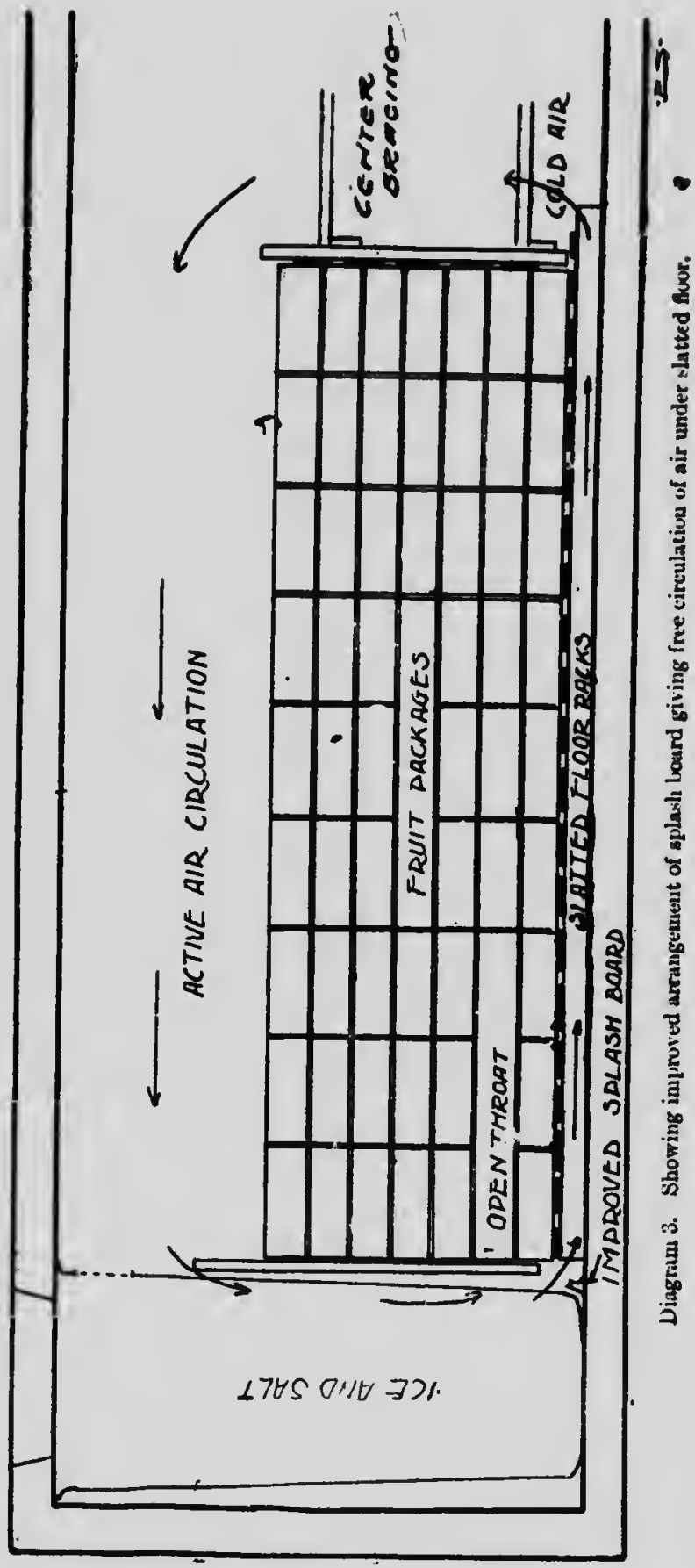




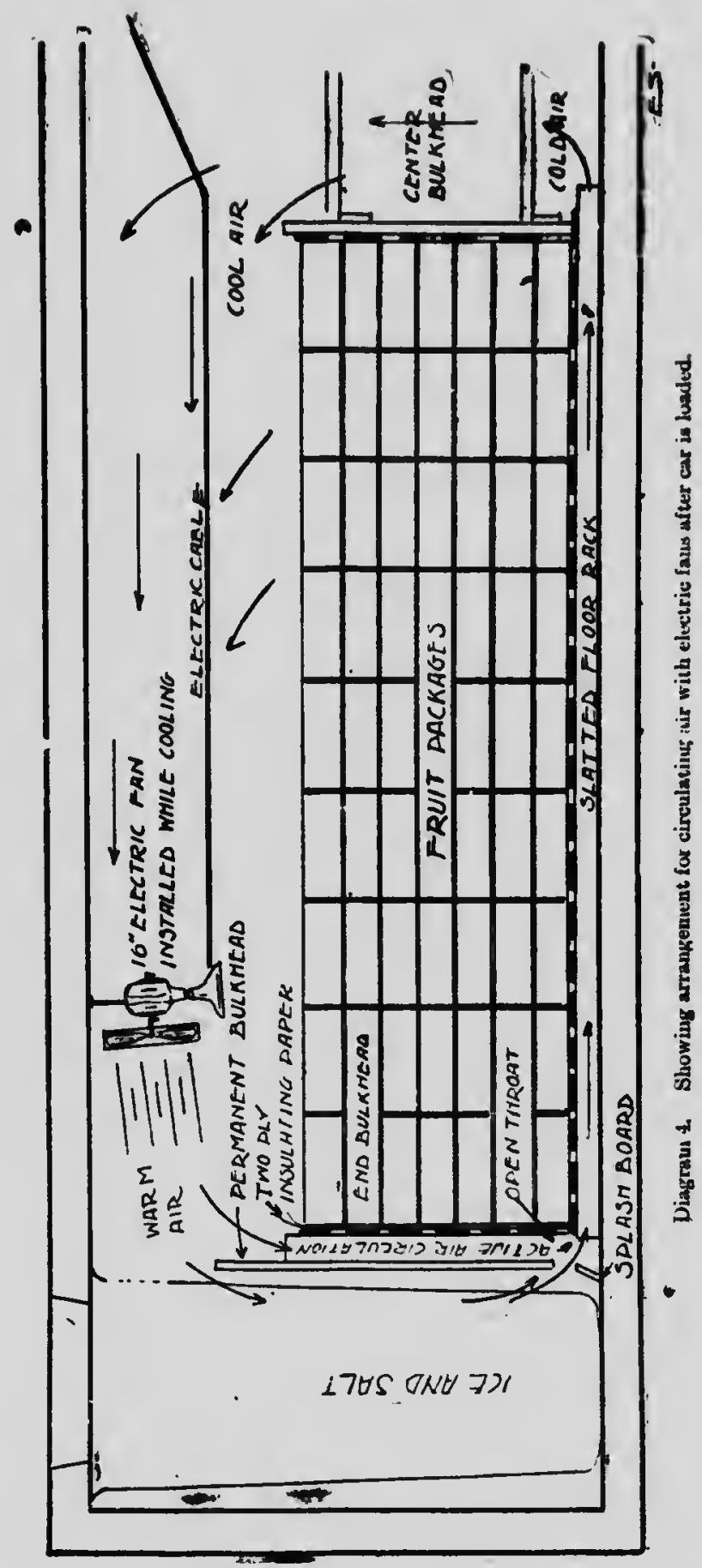




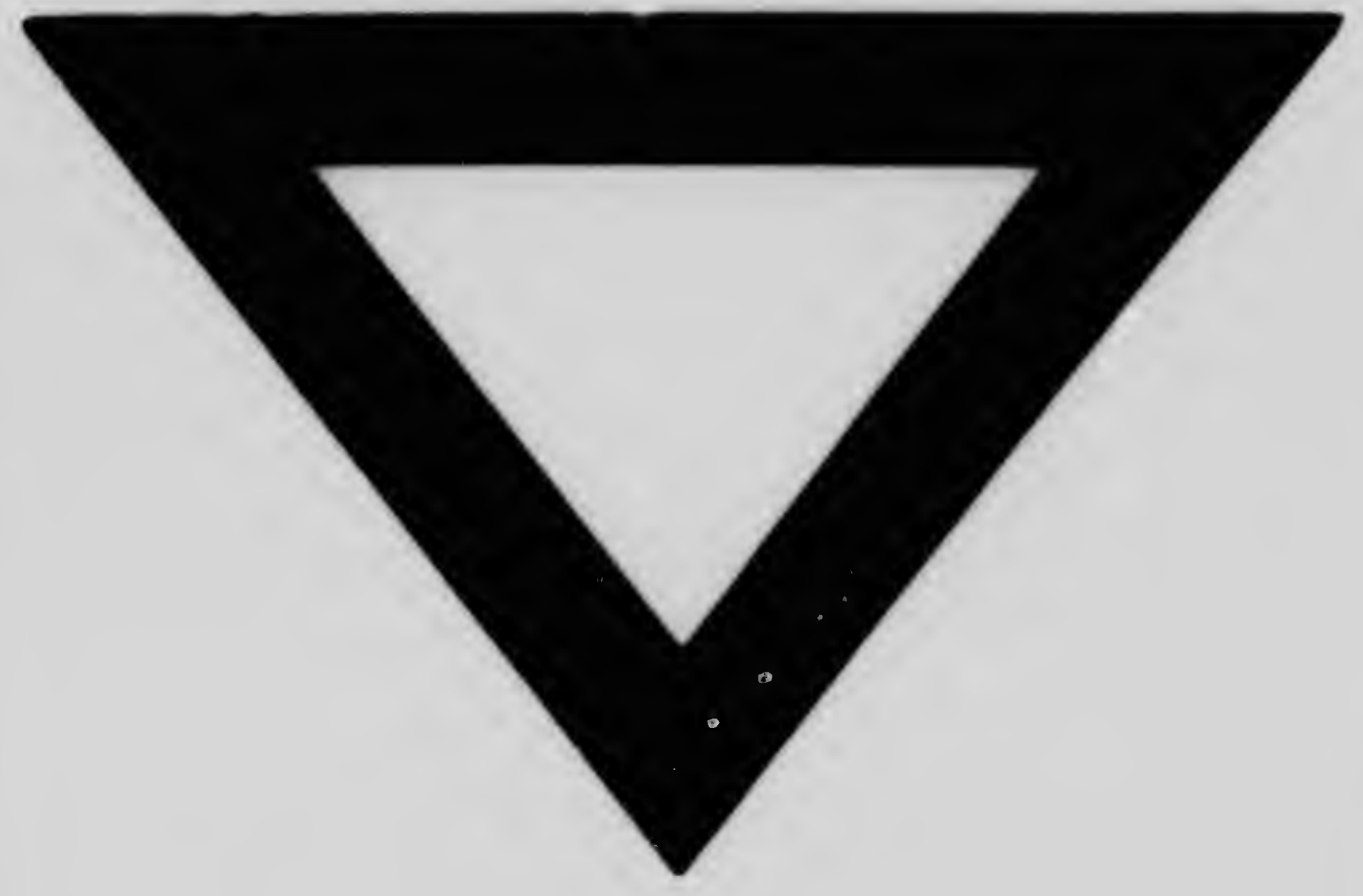

